DOI https://doi.org/10.36059/978-966-397-110-0/41-59

\title{
"ORGANISM" METAPHOR IN THE FORMATION OF THEORIES OF LOCAL CIVILIZATIONS
}

Kosmyna V. G.

\section{INTRODUCTION}

In humanitarian sciences in former Soviet Union countries, in particular in Ukraine, one of the most urgent tasks is a holistic understanding of social reality in the unity of human existence and thinking. The philosophers point out to the necessity of objectivesubjective cultural anthropological synthesis as well as "transparent" studying of spiritual and physical integrity of a person. S. B. Krymsky called axiological universe through which "the unity of ecology, ontology and praxeology is developing, providing firmly existence of civilization systems" as a fundamental field of philosophic range of problems. The philosophers and historians recognize the necessity of such synthetic approach to understanding of human history as well. Y.V. Pavlenko highlighted, that "human mind and science, in particular, by its nature, are striving to the holistic picture of the world as well as the past" 2 .

In understanding the history, civiliography based on the ground of local civilization theories offers such a comprehensive analysis. The theories were developed in more detail in the 19th-20th century by such well-known authors as M. Y. Danylevsky, O. Spengler, A. J. Toynbee. In spite of the differences between them, the endeavor of representation of the world history in connection and inter-conditionality with objective and subjective factors is common for them. This endeavor is based on organicism to one extent or another, being the methodology of explaining a set of social phenomena through analogy with living organism. One usually addresses to it when in the phenomena and in the processes studied they strive to show integrity, systematicity, dynamism, therefore, an "organic" unity.

Organicism as a way of understanding the integrity of natural, social, cultural phenomena was formed in the 19th century and, in time, it gave

\footnotetext{
${ }^{1}$ Кримський С.Б. Запити філософських смислів. К., 2003. С. 27.

Павленко Ю.В. Історія в калейдоскопі сучасних інтерпретацій. Нові перспективи історіописання / за ред. П. Берка; пер. $з$ англ. К., 2004. С. 377.
} 
life to the range of philosophic trends (existentialism, structuralism, and so on), today it still has a an independent significance for science, it has not exhausted its cognition potential. This is proved by regular references to it in the sociology and cultural science, namely, in society interpretation as social organism as well as in ethnos studies.

The very term "organism" is originated from the Medieval Latin "organizo" (to arrange, to give a slim look) and it means a living whole with its acting organs which are agreed (Greek organon - tool, instrument). Extrapolating it to the interpretation of the world or combinations of elements, the latter, as a rule, points to their integrity and ability to be developed. Organic vision can be rather persuasive because it appeals to something self-evident, it is based on direct perception of phenomena and human intuition. Thanks to it, it has an essential advantage over complex rational constructions, the evidence of which is still necessary to prove. One or other natural conceptions were the basis of various cosmogonic myths or ideas. It was believed that the world itself and its elements were created as a result of ritual separation of an ancient creature (an idol) and due to this circumstance they keep divine integrity. Such divine creatures are Vedic Purusha (Brahma), Chinese Pangu, Babylonian Tiamat, Scandinavian Ymir ${ }^{3}$. Christianity understands its church as Body of Christ as well and it is associated its life activity, impeccability and sanctity with the present of the Holy Sprit. According to the Western-European medieval worldview and it was a human society that was considered to be a hierarchical well-ordered "body" created by God, and various social states were considered to be its "organs" aimed at performing some or other functions. The entire human community and each historical form were defined through generalized category "universitas".

In the 19th-20th century organicism models were rather accepted in history of hilosophy and historiophilosophy. Analyzing the historical process, thinkers often referred to the modeling of "cycles of life" or "life cycles", mainly in the form of analogies with the cycles of individuals and cycles of generations. However, the historical science development itself was influenced by organicism insignificantly, despite of the fact, that it was urgent for its issues, in particular, connected with the civilization history. The reasons for the above mentioned as well as a general topic of

\footnotetext{
3 Элиаде М. Священные тексты народов мира. М., 1998. С. 85, 99-126.
} 
orgnicism applicability for the methodology of history were not specially studied in scientific literature.

Let us consider the issues of cultural and gnoseological origins of organicism in the formation of local theories of civilizations, first of all, "the great theories of civilizations" by M. Y. Danilevsky, O. Spengler, A. J. Toynbee in more detail and possibilities of overcoming its drawbacks in historical studies.

\section{Organicism in Understanding of the World History in the 18th-19th Century. M. Danilevsky's Theory}

In the New Age, the "organic" picture of the world influenced by rapid development of natural sciences began to emerge in the philosophy of history, but thinkers' approaches were different. In German philosophy, the romantic and conservative ideals had dominated since the $18^{\text {th }}$ century. I. Kant acknowledged that only causal-consecutive relationships operates in nature (the laws of nature), the which the natural science explored empirically and explained theoretically, but he saw the appropriateness (a "plan" of nature and a "plan" of history) in the structure and forms of life of living organisms, as in history, logically connecting history with biology specifically ${ }^{4}$. At the same time the idea of collective national (public) spirit, predetermining the specificity of social consciousness and defining the evolution of people and countries, was being developed.

J. G. Herder implemented these provisions in his works where he characterized the diversity of people's life on the Earth. In various nations he noticed such features of the organism as life time, morphology, growth, dynamism, as well as the closeness of the people's spirit and their focus on themselves not outside, but inside. Based on it, he defended an intuitive, hermeneutical, "understanding" approach to cognition of people's spirit, in particular, "through folklore, customs, clothing, and religion of people"

The very tradition of German "historical school" appeared under the joint influence of these ideas which was called "organology" by E. Troeltsch. Its "center of mass" is in the idea of public movement and its

\footnotetext{
${ }^{4}$ Колінгвуд Р. Дж. Ідея історії. К., 1996. С. 152-159.

5 Ионов И.Н., Хачатурян В.М. Теория цивилизаций от античности до конца ХІХ в. М., 2002. C. $95-96$.
} 
organic manifestation in integrity and development of the historical community mentioned ${ }^{6}$.

For a synthetic (holistic) comprehension of the historical "organism" cultural heritage during its period of formation, one need "an exact fantasy of feelings and interpretation", organic contemplation, "historical art", that is, metaphysical practice, or pure intuition; Schelling, personally, was the expert in it ${ }^{7}$. Close to "historical school" L. von Ranke wrote: "The historian is only an organ of spirit which, speaking by its own lips reveals himself for it, personally" $"$. The intuitive-organic method guided this school to the study of German culture and history, and in time - to other cultures as separate holistic organisms, while understanding of the world history was more and more difficult.

By that time in France and England there was a further converging between historical science and natural science, which in the 19th century achieved a great success. A philosophical doctrine of positivism was a guide for such convergence substantiated by A. Comte and developed by J. St. Mill. Positivism rejected all metaphysics and teleology and demanded relying exclusively on the methods of natural (positive) sciences, on the description and interpretation of sensory experience. The science of society, called sociology by Comte, was supposed to be a natural sciences discipline ("social physics"). The feelings of contentment and suffering (aspiration of the former and avoidance of the latter) were recognized as fundamental to a person, the interaction of which seems to provide the endless progress of mankind towards the achievement of a liberal ideal of maximum happiness for the maximum number of people, but at the same time it was not possible to trace some unity of the historical process, moved away from researcher's field of attention in the darkness of something incognizable like a "metaphysical mystery".

That is why the first generation of Comte's followers "referred to something that was biologic and organic explanation of social phenomena in their opinion"". It was facilitated by the very establishment of cell therapy of living organism structure at the end of 1830s. In accordance with it, a holistic organism formation takes place by combining differentiation of cells, tissues, organs and their integral interaction in the

\footnotetext{
${ }^{6}$ Трельч Э. Историзм и его проблемы. М., 1994. С. 238.

7 Трельч Э. Историзм и его проблемы. М., 1994. С. 2242-243.

${ }^{8}$ Цит. за: Копосов Н.Е. Как думают историки. М., 2001. С. 226.

9 Мизес Л. фон. Теория и история: Интерпретация социально-экономической эволюции. М., 2001. C. 176.
} 
organism. The English philosopher G. Spencer in his essay "The Social Organism" (1860) formulated the theory of social evolution, in which he showed that both organic evolution and social one ("super-organic") are equally subject to natural laws and take place in the area of divergent development and "growth of organizations" - the transition from less complex forms of structure to more complex ones ${ }^{10}$. According to Spencer, in history, this transition from indefinite unconnected homogeneity to a definite connected heterogeneity manifested itself in the evolution of mankind from primitive homogeneous nomadic groups into highly differentiated and integrated societies of the Western modern civilization.

This is how the positivist version of organicism was established, but it had a universalist Eurocentric nature and foresaw the inevitability of passing a single path of the Western civilization model by all people.

The German historian G. Rückert tried to deny such universalism. In the addition to the "Handbook of World History in Organic Version" (1857), he substantiated the idea of the simultaneous coexistence of various "cultural and historical organisms", which merger into the world whole is unlikely to happen. However, his book were unnoticed even in Germany, where its author is still not recognized as the original scientist ${ }^{11}$.

At the end, two versions of organicism mentioned (conservativeromantic and positivist) have become the methodological basis of the theory of local civilizations of Russian scientist M. Danilevsky (18221885), stipulated in his book "Russia and Europe. A Look at the Cultural and Political Relations of the Slavic World to the Germanic-Romanesque" (1869), in a rather specific combination. As usual, it is with this book that the development of a "multi-civilization" approach to history is associated.

The combination of positivism with organicism in the work of Russian scientist would not have been anything completely original, if, however, there were no two peculiarities. Firstly, Danilevsky was a convinced opponent of evolutionism and Darwinism and dedicated his criticism to the last two-volume work "Darwinism" (1885). Secondly, he was not a sociologist, a philosopher or a historian by his major; in

\footnotetext{
${ }^{10}$ Рэдклифф-Браун А. Р. Метод социальной антропологии. М., 2001. С. 276-279.

11 Ионов И.Н., Хачатурян В.М. Теория цивилизаций от античности до конца ХІХ в. М., 2002. C. $233-234,361$.
} 
particular, he was a biologist. The first circumstance, obviously, should not be interpreted as a sign of an unscientific nature of his views, since from the standpoint of even modern biology, organic evolution depends not so much on the laws of genetics but their violation (gene mutations). During the rule of Darwin's biology, anti-Darwinian concepts carried their scientific constructive elements.

The second circumstance ensured the full use of possibilities of biology to explain the historical development, what H. Rickert called the transformation into a "universal science of the world whole"12. Danilevsky unequivocally declared that for him it is strange to have a view, "which can not find anything similar in nature (where everything that has a beginning has an end, and finally, everything exhausts its content) in its confirmation." 13 (hereinafter the reference to this source is made in the text mentioning the pages in $-\mathrm{V}$. K.)

The reference point in the interpretation of a historical process by Danilevsky was a counterblast of the very human integrity. Not the human history which can not exist at all, but the history of certain cultural and historical types as independent "historic organisms" - that was his uncompromising logic.

However, this interpretation of mankind and people, on the contrary, allows Danilevsky to "put in order" the world history (in fact, the development of "historical organisms") through the natural system. $\mathrm{He}$ does not derive this system, as well as the entire theory of culturalhistorical types, from the analysis of historical facts, but literally transmits it from botany and zoology, "natural sciences in the narrow word sense", where it received "the widest, most complete development and implementation" (pp. 77, 83). A pattern for him is the distinction of representatives of the animal world by type of organization: "These types are not the essence of the degree of development ..., but completely different plans ... not having a common denominator ... This is, in fact, the values which are incommensurable" (p. 84), made by the French zoologist Georges Cuvier. Danilevsky has no doubt that the same can be said about civilization, which he calls cultural-historical types of development.

12 Риккерт Г. Философия жизни. Мн., М., 2000. С. 94.

13 Данилевский Н. Я. Россия и Европа: [взгляд на культурные и политические отношения славянского мира к германо-романскому]/ сост., послесловие и комментарии С. А. Вайгачева. М. : Книга, 1991. 
However, the differences between the types in zoology are too obvious for its classification methods to become universal. Therefore, Danilevsky (following Cuvier) believes that the true Copernican revolution throughout the natural sciences was carried out precisely in botany, where the look of plants does not directly reveal their morphology. Only due to the harmonious arrangement of plants, direct, "physiognomic" perception of their characteristics and the subsequent logical generalization Bernard and Antoine Jussieu were able to establish a natural system, and at the same time to justify the theory of the latter. And it involves such a grouping of objects or phenomena, when all their features are taken into account, and the relative advantage of these features is weighed and the objects are arranged in such a way when those belonging to a certain natural group have more connection, a stronger degree of similarity than with items from other groups (pp. 54, 149).

Since the theory works "for example and guidance to all other sciences", Danilevsky unconditionally applies it to history. "Forms of the historical life of mankind,- he writes, - as forms of flora and fauna, as forms of human art ... not only change and improve on the age, but also differ by cultural and historical types". And then he defines these types as "independent, certain plans of religious, social, domestic, industrial, political, scientific, artistic, in short, historical development" (p. 85).

The set of features itself, obviously, was compiled (as in botany) intuitively, by direct perception of social life. Such an organic vision of society objectively directed the study of the latter into a holistic, systematic study of all aspects of its life activity and promised a real methodological change in history and other social sciences. However, the author did not substantiate either the relationship between the features of the cultural-historical type, nor their set. And when he conducted a specific comparison of the Slavic and Germanic-Romanesque types in the book, he did it only on the basis of three criteria, which, moreover, had little correlation with the features indicated, - the mental system of people, their religion and "historical education".

At the same time, in accordance with the general spirit of biologism, he considered the mental order as determinant. It seems to have a direct influence on the choice of people of various religions, and, moreover, directly manifested itself in languages. In turn, for Danilevsky the language and psychological connection of a group of people was main 
reason for attributing them to one cultural-historical type. Although here he was often inconsistent: he united in one type two language groups - the Germanic and Romanesque, or reduced the analysis of Slavs to the characteristics of only the Russian people. Due to such a narrowing of the object of research to a particular people (the book refers primarily to the Russian ethnos) and the constant emphasis on national problems, researchers sometimes perceive the theory of cultural-historical types as a teaching of the nation.

However, the usual correspondence with biology was not enough to positively convey the historical development in its various aspects as a holistic and purposeful process persuasively. Therefore, Danilevsky had to include elements of metaphysics in his theory. He proposed the teleological "idea of development" in place of an explanation of the historical process. This was a manifestation of Kantianism (the principle of appropriateness) and Schilling's view (an intuitive comprehension of integrity) and a definite reflection of the various pre-Darwinian theories interpreted evolution as a purposeful process.

Danilevsky wrote that the historical life of mankind was developing in accordance with the "plan of the world-state Craft", but due to the direct effect of the divine Providence "both the harmonious order of nature and the history is impeccable" (pp. 214, 312). As a result, "the idea of a plant", "the idea of an animal", "the idea of a man", "the idea of a cultural-historical type" (the Slavs), "the idea of mankind" are treated by him as semantically identical concepts. Common to them was, in particular, a categorical denial of (in anti-Darwinist the spirit, of course) a single progressive development (of progress) of nature and human society. A relative evolution is only independent and distinctive and only within certain limits - it is possible only for certain species of animals and plants or for certain cultural-historical types. Therefore, "the full implementation of the plant idea is only in the whole variety of manifestations to which it is capable, in all types and at all stages of the development of the plant kingdom", and "the task of mankind is nothing more than manifestation, at different times and different tribes, all those sides, all those features of the range, which lie virtually (in opportunities, in potentia) in the idea of mankind" (p. 116).

Danilevsky named ten "well-known" cultural and historical types, or distinctive civilizations: Egyptian; Chinese; Assyrian-Babylonian- 
Phoenician, Chaldean, or Ancient-Semitic; Indian; Iranian; Jewish; Greek; Roman; New-Semitic, or Arabic; German-Romanian, or European (pp. 88), and then, having made analogies, added the Slavic type to this list as well. Although the scientist put them in a chronological order and some of them inherited certain achievements of their predecessors, this, in his opinion, does not indicate the unity and succession of all human history at all. Each of these "historical organisms" has its own unique way of development.

Danilevsky saw a direct analogy in the life of people and biological organisms: birth, the achievement of different stages of development, aging and death (p.74). Based on it, he defined four periods of life of cultural-historical types: ethnographic or formative (childhood); state (youth); civilization (maturity); time of exhaustion of creative forces, apathy of self-satisfaction or apathy of despair (old age), after which the people can become an ethnographic material for another culturalhistorical type (p. 106). At the same time, a civilization period is similar to the stage of flowering and fruiting in perennial monocotyledonous plants - it is relatively short and once and for all exhausting the vitality of the cultural-historical type. The people, who became old, lived their time, did their work, and if it is time for them to leave the stage, nothing will help, regardless of where they live - in the East or in the West. How and why this happens, how can the creative forces of entire societies weaken, according to Danilevsky, is completely beyond explanation (pp. 74, 168). $\mathrm{He}$, as a scientist-positivist, refused to go deep into the metaphysics of the ultimate causes of these phenomena. It turned out that in the mysterious "idea of development" (the plan of the world-state Craft) a well-defined, "biologically grounded" was only the fact that exhaustion of the content and death of cultural-historical types are inevitable.

The finalist concealed meaning of organicist analogies manifested itself in Danilevsky's denial of the ability of transferring civilization principles of one type to people of another type, and in affirming the completion of human progress in any direction. After one culturalhistorical type has reached a certain degree of excellence in the field for which it is the most capable, it is necessary to move from a new starting point and on a new way, "it is necessary that other psychic peculiarities come to the area of activity, another structure of mind, feelings and will, 
which only have people of other cultural-historical type"; the progress is to go all over the "field of historical activity" in all directions (p. 109).

So, if interpreting historical process in such a way, the issue of integrity of human history loses its sense indeed. The historical and cultural types (civilizations) as "supreme historical units" have become the subject of historical science (p.103).

The scientific significance of Danilevsky's theory is based on the fact that it started an urgent review of Europo-centric scheme of the world history. Organicism methodology guided science to a holistic and comprehensive analysis of society and its history. At the same time, the very logic of positivist organicism imposed a separate, even isolated, study of the history of civilizations, a strong distinction between "personal", immanent, and "foreign", borrowed, it forced to ignore the global context of events.

\section{Organic Influence in Civilizations Theories of the 20th Century}

For a half century having passed between the publication of Danilevsky's book and the publication of two-volume work of German philosopher Oswald Spengler (1880-1936), "The Decline of the West" (1918-1922) ${ }^{14}$, biology, namely, under the influence of C. Darwin, has achieved a great success and turned, according to $\mathrm{H}$. Rickert, almost in "universal science about the whole world" 15 . This was reflected in German philosophy, which, with its traditional orientation on spiritual factors, now has acquired the nature of the life philosophy and at the beginning of the 20th century became, according to H. Rickert, "the philosophical fashion of our days" $"$. The life philosophy saw a certain objectification of the true essence of the world in all individual things and phenomena - the will for life - (A.Shopenhauer), the will for power (F. Nietzsche), etc., and it called the experience of the researcher based on the formula: "life cognizes the life" (V. Dilthey, G. Zimmel) as the core of the methodology of all historical sciences - "the sciences of spirit". The philosophy of the history of the Baden School of Neo-Kantianism (W. Windelband, and especially H. Rickert) proclaimed an individualizing, or historical method as the method of "cultural studies" (as opposed to a generalized method of natural sciences), and the object of

\footnotetext{
${ }^{14}$ Шпенглер О. Закат Европы. Мн.: Харвест, М.: АСТ, 2000.

${ }_{15}^{15}$ Риккерт Г. Философия жизни. - Мн., М., 2000. - С. 94.

${ }^{16}$ Риккерт Г. Философия жизни. - Мн., М., 2000. - С. 8.
} 
research was the activity of people in creating value, in broad sense - the social activity of the formation of a unique culture system.

The influence of this studying also affected the theory of O. Spengler. In methodological terms, it was a decisive denial of positivist application of natural science methods, often used for studying (systematizing) the "dead nature", in the studying of the "living" history. "The striving for the system is the striving to kill the living things", - the philosopher emphasized $^{17}$. In this way it seemed to be fundamentally different from the method of Danilevsky, although there is no evidence that Spengler was familiar with his work. However, he called his way of thinking and observation in a similar way - the "physiognomy of the real". Physiognomy is "the morphology of organic, history and life; all that is subordinated to the direction and destiny" 18 . The forms of culture are the holistic organic forms of history, with eight cultures-organisms being marginal and the largest among them, which in the early 20th century were already described in detail in the scientific literature. He applies a method of comparative morphology of the world history to them.

Unlike Danilevsky, who saw a system of facts united by a metaphysical "plan" in the cultural-historical type, Spengler finds the substantive basis of the life of culture - its soul as an irrational set of opportunities to be realized. Their realization is life, formation, but something that has been already accomplished, namely, the world, the steady, and the dead ${ }^{19}$. When a soul performs the full amount of its opportunities "in the form of people, languages, beliefs, arts, states and sciences" in the external world and returns to the original spiritual element, then the culture "suddenly freezes, dies, its blood crumbles, the forces are broken - it becomes civilization" ${ }^{20}$ [Spengler O. The Decline of Europe - Mn.: Harvest, M.: AST, 2000. 0, pp.167-168]. At the same time, Spengler also states that each culture, by analogy with biological organisms, is born, consistently passes stages of youth, maturity, old age and dies; and that all cultures have the same duration of these periods and a homologous equivalent structure ${ }^{21}$. Based on these "biological laws", he predicted the meaning of future centuries of the Western history, its

${ }_{17}^{17}$ Шпенглер О. Закат Европы. Мн.: Харвест, М.: АСТ, 2000. С. 689.

18 Шпенглер О. Закат Европы. Мн.: Харвест, М.: АСТ, 2000. С. 158, 717.

${ }_{19}$ Шпенглер О. Закат Европы. Мн.: Харвест, М.: АСТ, 2000. С. 160.

${ }^{20}$ Шпенглер О. Закат Европы. Мн.: Харвест, М.: АСТ, 2000. С. 167-168.

${ }^{21}$ Шпенглер О. Закат Европы. Мн.: Харвест, М.: АСТ, 2000. С. 173-175. 
inevitable decline and death - by analogy with the last centuries of previous culture life.

The way Spengler proposed to comprehend the deep meaning of cultural creations is methodologically significant. The historian has to reproduce in his own experiences the experiences of people of relevant epochs, to look at the world around with own eyes. The historian has to perceive specific things only as symbols, and not in their individuality, but in the universal cultural unity of style. However, empathy is not so necessary here, but a high level of intuition, a "physiognomic tact", characterized as "an unconscious method of instinctual consideration of the world process" 22 . German philosopher reveals the first principle of culture with his intuitive, artistic comprehension of the style of culture its presymbol defining the nature and meaning of all its symbols, so one can make the typology of cultures.

Therefore, the power of Spengler's method manifested itself in its ability to immediately capture the entire reality, the whole set of historical facts, that was impossible with any other methodology such as Hegelian, Marxist, positivist, or Neo-Kantian. The historian should ignore neither experience nor imagination, intuition, since the very nature of scientific cognition, especially in history, foresees their presence in the methodological tools of the scientist. The vulnerability of this method is in the fact that one has to appeal to metaphysics - the idea of the "organism", "destiny", "soul", "presymbol", etc., comprehended purely psychologically, intuitively and not subject to any verification. In addition, Spengler was able to show only culture isolation, a priori insisting on the organic closure, the mutual impenetrability of cultures. Due to this own "closure" of his theory, the latter did not get extended in other concepts of the same meaning.

However, at the time when the life philosophy and the varieties of organicism, connected with it, were dominated in Germany, another experience in the culture study was accumulated in England and France. French philosophers and sociologists continued the tradition, laid down by A. Comte. They recognized the differences between cultures, but they analyzed them from the view of "reality". H. Taine studied the influence on the culture of climate, race, geographical conditions, and E. Durkheim studied the influence on the state and development of collective

\footnotetext{
${ }^{22}$ Шпенглер О. Пессимизм ли это? Шпенглер О. Пессимизм? М., 2003. С. 12.
} 
consciousness and its associated forms of "mechanical" and "organic" solidarity of individuals. In the historical and sociological thought of England, Spenser's evolutionary theory of the development of a social organism and J. St. Mill's theory (law) of the increase in consequences under the same causes, in particular geographical ones, preserved their influence. H. T. Buckle proposed his own theory of civilizations, in which he linked the peculiarities of the society development with a specific state of the geographical environment. He explained the fundamental differences between European and non-European types of civilizations based on $i^{23}$. So, the versions of the theory of local civilizations were also developed in France and England, moreover, on a positivist basis. It prepared the ground for a new and fundamental theory, proposed by English historian Arnold Joseph Toynbee (1889-1975), the author of the 12-volume "A Study of History" (1934-1961). In Ukraine, this work is published in the 2-volume short version of D. C. Somervell, approved by the author ${ }^{24}$.

A. J. Toynbee admitted that he was inspired by disagreement with Spengler to this work, "an impressive dogmatic person and determinist", in whose works all civilizations passed a single life cycle for a wellestablished and unexplained schedule: "If German a priori method has failed, it is worth trying what can be achieved with English empiricism"25. So, Toynbee just put organicism as the "blame" on Spengler. He categorically stated that "societies can not be compared with living organisms", that "civilizations are a reality of a kind not subject to the laws of biology"26. He based his great picture of the history of civilizations on the involvement of a huge range of historical facts, mainly those relating to political, economic and cultural history. Having grouped and compared them, he revealed the diversity of civilizations in the history of mankind, which totaled 37, including those which reached full prosperity (13), and those which ceased to exist in the early stages of growth.

However, he did not avoid organicism and biology. Obviously, the idea of classifying and systematizing historical material itself is programmed by external, sometimes very spontaneous, structuring and

${ }^{23}$ Ионов И.Н., Хачатурян В.М. Теория цивилизаций от античности до конца ХІХ в. М., 2002. C. $242-248$

${ }^{24}$ Тойнбі А. Дослідження історії. Том 1. К., 1995; Тойнбі А. Дослідження історії. Том 2. К., 1995.

25 Тойнби А.Дж. Цивилизация перед судом истории: Сборник. М., 2003. С. 271.

26 Тойнбі А. Дослідження історії. Том 1. К., 1995. С. 248-249. 
interpretation of facts, as Danilevsky did at his time. R. G. Collingwood wrote that the general concept of Toynbee's history "is extremely naturalistic; he considers the life of any society as a natural life, and not spiritual, as something purely biological in its basis, which is the best to understand through biological laws"27. Indeed, his civilizations act as living individuals. They adapt to a particular environment, first of all, geographic, looking for effective "responses" on the "challenges" of the latter. Actually, the system of challenge-and-response creates "incentives" for genesis, growth, decline and collapse of civilizations. The internal structure of different societies at different stages is also quite similar. Therefore, Toynbee's critical remarks on Spengler's concept of history can, to some extent, be redirected to his own. Though, in contrast to Spengler and Danilevsky, he recognizes a certain connection (affiliation) of civilizations and the possibility of forming world civilization with the universal church on the basis of Christianity in the future.

Toynbee's theory is extremely valuable to historical science, since it interprets the factual material most widely among all existing theories of civilizations and it is best provided with evidences. However, it does not create a reliable methodology for historical research. First of all, just because of the fact that its author did not act as a methodologist of history, or just as a historian, but as a philosopher of history. He saw his task in creating a general panorama of the world history, in organizing a great number of historical facts (for this purpose moderate organicism is quite acceptable), rather than developing a methodology for a civilization analysis of the historical process.

However, these versions of the theory of local civilizations though played a prominent role in the evolution of historical thought, but remained at the level of philosophical understanding of history. The integrity of the history of civilizations, the coherence of historical facts in it, was covered mainly intuitively and aesthetically. The theories mentioned above were not enough associated with the practice of historical research: they did not arise from it and they were little influenced by it, because they did not give reliable methodical and methodological tools for linking either facts or sources of information.

In this sense, the systems-communicative theory of the prominent German sociologist, Niklas Luhmann discovers the new methodological

\footnotetext{
${ }^{27}$ Колінгвуд Р. Дж. Ідея історії. К., 1996. С. 231.
} 
opportunities. It gained its completed form in the general work "Society of the Society" (1997) ${ }^{28}$. Its advantage is in the fact that the immanent systematic relation of historical facts, historical sources in their sequential or reactive meaningful correlation as well as the immanent procedurality of events in social systems is revealed. The theory states that society as such does not include people but communications, allows us to overcome the most difficult problem for historical science of subjective-objective dichotomy of both facts and sources. The phenomenon of communication (namely, every fact of history, every historical source) removes the question of the objective and subjective from the agenda, since communication is both of them ${ }^{29}$.

And since the internal system coherence of historical facts as semantic communications remains crucial for the methodology of the civilization analysis of the historical process, it is in the aspect of the study of the external, stylistic unity of each civilization that the communicative approach to the history of civilizations finds many points of intersection with the philosophical and historical civilization theories of M. Y. Danilevsky, A. Toynbee, O. Spengler and other thinkers, mainly based on external observation positions. Preconditions are created in order to re-evaluate the above-mentioned theories, now taking into account the prospects of a civilization analysis of history by means of historical science.

In some cases it is possible to bring a reliable methodological base to a number of brilliant intuitions of these thinkers, especially with regard to the internal integrity of civilizations, while in others, it is necessary to adjust or simplify theoretical statements. Thus, many civilization theories, having "organism" analogies, acquire a logical justification, since both living organisms and civilizations function as self-referential autopoietic systems, the autopoiesis of which started once and can be completed one day. It is now when the metaphor of "organism" can be replaced by the study of internal meaningful coherence of facts. In general, A. Toynbee's list of modern civilizations seems to be more or less justified from a methodological point of view, since it is bound to certain religious communication systems.

\footnotetext{
${ }^{28}$ Luhmann N. Die Gesellschaft der Gesellschaft / Niklas Luhmann. Frankfurt am Main: Suhrkamp Verlag, 1997. 1150 S.

${ }_{29}$ Докладніше тут: Космина В.Г. Цивілізаційний аналіз історії в світлі системної теорії Н. Лумана. Український історичний журнал. 2010. №1. С. 165-178.
} 
Toynbee's mechanism of the "challenge-and-response" as an incentive for the development of civilization can now be described at the factual level as an internal restructuring of the meaningful communication system in response to external stimuli. At the same time, Toynbee's concept of "mimesis", coinciding with the idea of English ethologist R. Dawkins about the transfer of "mimes" as units of cultural imitation, also requires certain clarifications. One can speak only about the selection of new communication meanings in certain communication systems in a well-argued manner.

In recent centuries the civilization specificity of the West is also clarified. Depending on the chosen position of observation (of course, the first order), philosophers either described these times as a "decline" of European culture (O. Spengler), or, one-sidedly interpreted the New European society as "capitalistic", "industrial", "liberal", etc. overemphasizing the role of certain functional areas. In fact, the Western transition from the traditional hierarchical form of system differentiation with the regulatory role of religious communications to a functionally differentiated society was taking place.

\section{CONCLUSIONS}

Summarizing the study conducted, it is worth noting the following. An organic holistic vision of historical phenomena and processes in their integrity of material and spiritual components remains vital for humanitarian sciences today. The organism methodology of history understanding was developed mainly in the 19th centuries in two following versions: conservative and romantic (German) and, in a less degree, positivistic (English-French). It found its implementation, first of all, in the theories of local civilization. In Danilevsky's theory both versions with the significant prevalence of one of them were united. Spengler's theory was based on the first one and was directed to the search of fundamental principle (presymbol) of each culture-organism. Toynsbee's theory was rich with actual material and it carried certain imprint of positivistic organicism.

In these theories the analogy with an organism and even an "organism" metaphor was used. The theory of cultural-historical types by M. Danilevsky, the theory of cultures-organisms by O. Spengler, the theory of civilizations as individuals by A. Toynbee made efforts to cover 
all the facts of history of one or another civilization together in its organic connection by a single view and a single thought. However, all these theories were formed within the framework of the philosophy of history and did not provide for the creation of methodology of the same "organic" analysis of either historical facts or historical phenomena and processes.

In these theories the consideration of historic processes was built not on the study of historic facts themselves as well as the establishment of internal connection between them, but, mainly, on insertion of facts already discovered by science in the philosophic schemes of the thinkers based on "organic" analogy. In fact, the civilization vision is introduced as a part of prior knowledge.

That is why the issue of the development of relevant methodology, in particular, in the field of a comprehensive analysis of social communications is not removed from the agenda.

Meanwhile, a modern post-non-classical science takes the very concept of the integrity of the world structure, society, and civilization as a basis. Luhmann's post-neo-classical sociologic theory, just developed in the 20th century, points out to immanent systematic coherency of historical facts, historical sources in their consequent or reactive meaningful correlation, and thus, to the coherency of the historical process in general. It creates methodological opportunities for holistic studying of civilizations by way of the historical science itself.

\section{SUMMARY}

The article analyses the origins, role and place of an "organism" metaphor in the civilization analysis of the historical process. As a rule, it appeared as a suitable means of connection of numerous historical facts, especially where it was necessary to emphasize such features of the world as integrity and ability to develop. An organism has been present for a long time in various religious systems, forming the basis of cosmogonic myths and "the world pictures". In the 19th century, it took an essential place in the philosophy of F. W. J. von Schelling and the historiosophy of German "historical school" in the form of metaphysical organology. Sociologists-positivists (H. Spenser, at all) in search of an explanation for social phenomena also turned to organicism ("social biology"), strengthened by the authority of Darwin's theory of the origin of species. 
The authors of local civilizations theories began to apply the "organism" metaphor even in more active way. The theory of cultural and historical types by M. Danilevsky, the theory of cultures-organisms by O. Spengler, the theory of civilizations as individuals by A. Toynbee made efforts to cover all the facts of history of one or another civilization together in its organic connection by a single view, a single thought. However, all these theories were formed within the framework of the philosophy of history and did not provide for the creation of methodology of the same "organic" analysis of either historical facts or historical phenomena and processes.

Luhmann's systems-communication theory discovers new opportunities for studying internal integrity and coherence of historical process by means of historical science which is exactly based on the principal recognition of immanent systematicity and immanent procedurality of event in social systems. It can even prove organic metaphors and assumptions in the theory of local civilizations.

\section{REFERENCES}

1. Кримський С.Б. Запити філософських смислів. К., 2003. С. 27.

2. Павленко Ю.В. Історія в калейдоскопі сучасних інтерпретацій. Нові перспективи історіописання / за ред. П.Берка; пер. $з$ англ. К., 2004. С. 377

3. Элиаде М. Священные тексты народов мира. М., 1998. С. 85, 99-126.

4. Колінгвуд Р. Дж. Ідея історії. К., 1996. С. 152-159, 231.

5. Ионов И.Н., Хачатурян В.М. Теория цивилизаций от античности до конца ХІХ в. М., 2002. С. 95-96, 233-234, 242-248, 361.

6. Трельч Э. Историзм и его проблемы. М., 1994. С. 238, 242-243.

7. Копосов Н.Е. Как думают историки. М., 2001. С. 226.

8. Мизес Л. фон. Теория и история: Интерпретация социальноэкономической эволюции. М., 2001. С. 176.

9. Рэдклифф-Браун А. Р. Метод социальной антропологии. M., 2001. C. 276-279.

10. Риккерт Г. Философия жизни. Мн., М., 2000. С. 8, 94.

11. Данилевский Н. Я. Россия и Европа : [взгляд на культурные и политические отношения славянского мира к германо-романскому] / сост., послесловие и комментарии С. А. Вайгачева. М. : Книга, 1991. 
12. Шпенглер О. Закат Европы. Мн.: Харвест, М.: АСТ, 2000. C. $158,167-168,173-175,689,717$.

13. Шпенглер О. Пессимизм ли это? Шиенглер О. Пессимизм? M., 2003. C. 12.

14. Тойнбі А. Дослідження історії. Том 1. К., 1995. С. 248-249.

15. Тойнбі А. Дослідження історії. Том 2. К., 1995.

16. Тойнби А.Дж. Цивилизация перед судом истории: Сборник. М., 2003. С. 271.

17. Luhmann N. Die Gesellschaft der Gesellschaft/ Niklas Luhmann. Frankfurt am Main: Suhrkamp Verlag, 1997. 1150 S.

18. Космина В.Г. Цивілізаційний аналіз історії в світлі системної теорії Н. Лумана. Український історичний журнал. 2010. №1. C. $165-178$.

\section{Information about the author: Kosmyna V. G.}

Doctor of Historical Sciences, Assistant Professor at the Department of Philosophy and History Educational and Scientific Humanitarian Institute of V. I. Vernadsky Taurida National University, 33, Ivana Kudri str., Kyiv, Ukraine. 